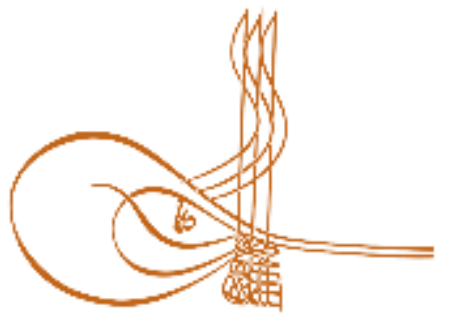

www.turkishstudies.net/turkishstudies
Turkish Studies

eISSN: $1308-2140$

Research Article / Araştırma Makalesi

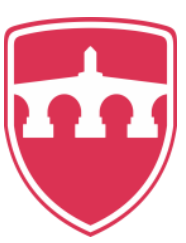

INTERNATIONAL

BALKAN

UNIVERSITY

Sponsored by IBU

\title{
Sınıf Öğretmenleri ile Sınıf Öğretmeni Adaylarının Sosyal Beceri Öğretimine İlişkin Bilgi Düzeylerinin Karşılaştırılması"
}

\author{
Comparison of Classroom Teachers' and Preservice Teachers' Level of Knowledge Regarding \\ Social Skills Teaching
}

Sevda Kılıç**

\begin{abstract}
In this study, in which the general survey model was used, the purpose is to review the classroom teachers', who have students with special needs in their classrooms, and preservice teachers' level of knowledge regarding social skills teaching in terms of various parameters. 2 separate samples were used to create the research group. While the criterion sampling method under the title of purposeful sampling was preferred when determining the classroom teachers, convenient sampling method was used when determining the preservice teachers. Thus, in this regard, 61 classroom teachers who have students with special needs in their classrooms in the city center of Kars, and 81 senior students who are studying at classroom teaching department in Kafkas University Dede Korkut Faculty of Education participated the study. In the study, as the data collection tool, the "Personal Data Form" (PDF) created by the researcher as well as the "Social Skills Teaching Knowledge Test" (SSTKT) developed by Sazak Pınar in 2009 were used with necessary permissions. Various descriptive and educible statistics were utilized in the analysis of the data obtained from the study, and in accordance with the obtained findings, while the highest score to get from SSTKT is Max.=23,00, the classroom teachers who participated the study scored $\bar{X}=11,60$ in average, and the preservice teachers scored $\bar{X}=11,81$ in the test. Thus, it was concluded that the classroom teachers' and preservice teachers' level of knowledge regarding social skills teaching was medium level and did not differ significantly. Moreover, in accordance with the findings obtained from the study, it was found that the classroom teachers' and preservice teachers' level of knowledge regarding social skills teaching did not differ significantly in terms of the parameters of gender, age, professional service time, graduated high school, and university department.
\end{abstract}

Structured Abstract: Considering the fact that social skills are important and functional skills in terms of the individuals', both with normal developmental characteristics and special education needs, ability to live as efficient and independent individuals in the society, the purpose of this study is to review and compare the classroom teachers' and preservice teachers' level of knowledge regarding social skills teaching in terms of various parameters.

\footnotetext{
* Bu araştırma 6-9 Kasım 2019 tarihleri arasında gerçekleştirilen 29. Uluslararası Katılımlı Ulusal Özel Eğitim Kongresi'nde sözlü bildiri olarak sunulmuştur.

*** Arş. Gör., Kafkas Üniversitesi, Dede Korkut Eğitim Fakültesi, Özel Eğitim Bölümü Res. Asst., Kafkas University, Faculty of Education, Department of Special Education ORCID 0000-0003-1522-654X sevdakilic@yahoo.com

Cite as/ Atıf: Kılıç, S. (2020). Sınıf öğretmenleri ile sınıf öğretmeni adaylarının sosyal beceri öğretimine ilişkin bilgi düzeylerinin karşılaştırılması, Turkish Studies, 15(2), 1101-1120. https://dx.doi.org/10.29228/TurkishStudies.40099

Received/Geliş: 10 December/Aralı 2019 Checked by plagiarism software

Accepted/Kabul: 25 April/Nisan $2020 \quad$ Published/Yayın: 30 April/Nisan 2020

Copyright (C) MDE, Turkey 
2 separate samples were used to create the research group. When determining the classroom teachers, the criterion sampling method under the title of purposeful sampling was used. When determining the preservice teachers, the convenient sampling method was preferred, and it was aimed to reach the maximum possible number of participants. Thus, in this regard, 61 classroom teachers who have students with special needs in their classrooms in the city center of Kars, and 81 senior students who are studying at classroom teaching department in Kafkas University Dede Korkut Faculty of Education participated the study.

In this study where the general survey model was used, as the data collection tool, the "Personal Data Form" (PDF) created by the researcher as well as the "Social Skills Teaching Knowledge Test" (SSTKT) developed by Sazak Pınar in 2009 were used with necessary permissions. In the Personal Data Form developed for classroom teachers, there are 4 questions as gender, age, graduated university department, and professional service time, while there are 3 questions as gender, age, and graduated high school in the Personal Data Form developed for preservice teachers. In addition, in the first part of SSTKT consisting of two parts, there are 13 multiple-choice questions about the problem status of social skills notion as well as teaching methods and techniques of teachers, while there are 5 short-answer questions in the second part (18 questions in total).

While only the descriptive statistics (frequency distribution, central tendency, and variability measures) were utilized when making the data obtained from PDF meaningful, both descriptive statistics and educible statistics were used when making the data obtained from SSTKT meaningful. In this regard, at the stage of determining the proper educible statistics technique, first of all, the preliminary analyzes (ShapiroWilk, Kolmogrov-Smirnov, and examination of Skewness-Kurtosis values) required to inspect the normality of the distribution of each parameter were conducted, and as a result of these analyzes, it was observed that the data sets did not display any normal distribution, and non-parametric tests were used. Accordingly, in order to determine if the classroom teachers' and preservice teachers' level of knowledge regarding social skills teaching differs significantly based on the gender parameter, the non-parametric Mann Whitney U test was conducted; however, Kruskal Wallis $\mathrm{H}$ test was conducted in order to determine if the level of knowledge differs significantly based on the age, professional service time, graduated high school, and university parameters.

In accordance with the findings obtained from the study, while the highest score to get from SSTKT is Max. $=23.00$, the classroom teachers who participated the study scored $\overline{\mathrm{X}}=11.60$ in average, and the preservice teachers scored $\bar{X}=11.81$ in the test. Thus, it was concluded that the classroom teachers' and preservice teachers' level of knowledge regarding social skills teaching was medium level and did not differ significantly. Moreover, in accordance with the findings obtained from the study, it was found that the classroom teachers' and preservice teachers' level of knowledge regarding social skills teaching did not differ significantly in terms of the parameters of gender, age, professional service time, graduated high school, and university department.

Hence, in this regard, the finding that both the classroom teachers' and preservice teachers' level of knowledge regarding social skills teaching is medium level shows discrepancy to the previous research findings. In a study conducted by Sazak Pinar (2013) in order to determine the inclusive class teachers' level of knowledge regarding social skills teaching and to research if their classroom level and education made a difference on their level of knowledge, it was observed that the teachers scored 3 at minimum, 15 at maximum, and 9.85 in average from SSTKT, in which the maximum possible score is 23 , and it was concluded that the teachers' level of knowledge regarding social skills teaching was limited. Moreover, in another study conducted by Sazak Pinar (2012), it was aimed to determine the preservice teachers' level of knowledge regarding social skills teaching and to research if their level of knowledge regarding social skills teaching varied based on their program type, and accordingly, it was found that the preservice teachers' level of knowledge regarding social skills teaching was limited. In another study conducted by Güner Y1ldız (2017) that presents the inadequacy of the teachers' level of knowledge regarding social skills teaching, it was observed that the classroom teachers scored 12.4 in average from SSTKT, in which the maximum possible score is 23, and it was concluded that gender parameter did not have any impact on the teachers' level of knowledge regarding social skills teaching. Moreover, in literature, there are other studies (Cheney \& Barringer, 1995; Çolak, Vuran, and Uzuner, 2013; Dobbins \& Higgins, 2010; Lane, 1999; Lane, O’Shaughnessy, Lambros, Gresham, and Beebe-Frankenberger, 2001; Lane \& Menzies, 2005; Vlachou, Stavroussi, and Didaskalou, 2016; Vuran \& Çolak, 2007) that examine teachers' level of knowledge regarding social skills teaching by using different research methods. In these studies, too, it was found that the teachers' level of knowledge regarding social skills teaching was limited.

Turkish Studies, 15(2) 
As a result, classroom teachers, who have students with special needs in their classrooms, as well as preservice teachers need to take responsibility at the point of teaching social skills to all students with different potentials, or physical and/or mental characteristics. In accordance with this necessity, social skills teaching must non-arbitrarily be a part of education programs, and students must be given opportunities so that they can use their social skills, which they gained at school, in their natural habitat, and can improve their social capability.

Keywords: Level of knowledge regarding social skills teaching, classroom teacher, preservice teacher, mainstreaming.

Öz: Genel tarama modelinin kullanıldığı bu araştırmada, sınıfında özel gereksinimli öğrenci bulunan sınıf öğretmenleri ile sınıf öğretmeni adaylarının sosyal beceri öğretimine ilişkin bilgi düzeylerinin çeşitli değişkenler açısından incelenmesi amaçlanmıştır. Araştırma grubunun oluşturulmasında 2 ayrı örneklem kullanılmıştır. Sınıf öğretmenlerinin belirlenmesinde amaçsal örnekleme başlığı altında ölçüt örnekleme yöntemi tercih edilirken, sınıf öğretmeni adaylarının belirlenmesinde ise kolay ulaşılabilir örnekleme yöntemi tercih edilmiş̧ir. Nitekim bu bağlamda, araştırmaya Kars il merkezinde sinıfinda özel gereksinimli öğrenci bulunan 61 sınıf öğretmeni ile Kafkas Üniversitesi Dede Korkut Eğitim Fakültesi’nde sınıf öğretmenliği bölümünde okuyan 81 son sınıf öğrencisi katılmıştır. Araştırmada veri toplama aracı olarak, araştırmacı tarafından oluşturulan "Kişisel Bilgi Formu (KBF)" ve 2009 yılında Sazak Pınar tarafindan geliştirilen "Sosyal Beceri Öğretimi Bilgi Testi (SBÖBT)" gerekli izinler alınarak kullanılmıştır. Araştırmadan elde edilen verilerin analizinde çeşitli betimsel ve anlam çıkartıcı istatistiklerden yararlanılmış olup elde edilen bulgular doğrultusunda, SBÖBT'ten alınabilecek en yüksek puan Max.=23.00 iken; araştırmaya katılan sınıf öğretmenlerinin testten ortalama $\bar{X}=11.60$, sınıf öğretmeni adaylarının ise $\bar{X}=11.81$ puan aldıkları belirlenmiştir. Dolayısıyla sınıf öğretmenleri ile sınıf öğretmeni adaylarının sosyal beceri öğretimine ilişkin bilgi düzeylerinin orta düzey olduğu ve birbirlerinden anlamlı düzeyde farklılaşmadığı sonucuna ulaşılmıştır. Ayrıca araştırmadan elde edilen bulgular doğrultusunda öğretmen ve öğretmen adaylarının sosyal beceri öğretimine ilişkin bilgi düzeylerinin cinsiyet, yaş, mesleki hizmet yılı, mezun olunan lise türü ve üniversite bölümü değişkenleri açısından anlamlı düzeyde farklılaşmadığı sonucuna ulaşılmıştır.

Anahtar Kelimeler: Sosyal beceri öğretimi bilgi düzeyi, sınıf öğretmeni, sınıf öğretmeni adayı, kaynaştırma.

\section{Giriş}

Bireyin içinde bulunduğu topluma uyum sağlayabilmesi ve bağımsız bir birey olarak yaşamını sürdürebilmesi; içinde bulunduğu toplumun tutumlarını, değer yargılarını, davranış kalıplarını ve kendisinden beklenen davranış örüntülerini öğrenmesiyle yani sosyal gelişimini sağlıklı bir şekilde tamamlamasıyla mümkün görülmektedir. İnsan doğduğu andan itibaren toplumsal yaşamın bir parçası haline gelirken, aileyle başlayan ilk sosyal etkileşimler bireyin yaşamı boyunca farklı sosyal ortamlarda varlığını sürdürmektedir. Nitekim bu bağlamda bireyin bu farklı ortamlarda kabul görmesini sağlayacak birtakım uygun sosyal becerilere sahip olması beklenir (Olçay Gül, 2018).

Alanyazın incelendiğinde, farklı disiplin alanlarının üzerinde çalıştı̆ğ konulardan biri olması nedeniyle araştırmaya konu olan "sosyal beceri" kavramının farklı biçimlerde tanımlandığı görülmektedir. Sosyal beceriler Elliott ve Gresham (1993) tarafından bireye çevresiyle etkileşim firsatı sunan, sosyal açıdan kabul edilen ve olumlu tepkiler ortaya çıkaran öğrenilmiş davranışlar olarak tanımlanırken; Margalit (1993) tarafından belirli bir amaca yönelik olarak kullanılan, toplumsal değer yargılarıly belirlenen, bireyin içinde yaşadığı sosyal ortama ve duruma göre değişebilen, nötr veya olumlu tepkiler ortaya çıkartabilecek şekilde bireyin başkalarıyla etkileşim halinde olmasını sağlayan ve çevreden olumsuz tepkiler almasını önleyen öğrenilmiş davranışlar olarak tanımlanmıştır. 
Sosyal becerilere ilişkin farklı tanımlar incelendiğinde sosyal becerilerle ilgili bazı ortak özelliklerin olduğu görülmektedir. İlgili alanyazında yer alan bu ortak özellikleri şu şekilde özetleyebiliriz.

Öğrenilmiş davranışlar olan sosyal beceriler sözel ve sözel olmayan davranışlardan, gözlenebilen becerilerin yanı sıra gözlenemeyen bilişsel ve duygusal ögelerden oluşur. Amaca yönelik olan ve birey tarafından belirlenen bir amaç için kullanılan sosyal beceriler, bireyin içinde yer aldığı toplumun sosyal kurallarına bağlıdır. Bireyin diğerleriyle ve çevresiyle etkileşimi sonucunda oluşan sosyal beceriler; bireyin içinde yaşadığı toplumun sosyal kurallarına bağlı olan, bireyin sosyal ortamlarda olumlu ya da nötr tepkiler almasını ya da olumsuz tepkilerden kaçınmasını sağlayan becerilerdir (Ergenekon, 2017; Sucuoğlu ve Çifci, 2001; Olçay Gül, 2018).

Ayrıca ilgili alanyazında kimi zaman sosyal yeterlik ve sosyal beceri kavramlarının birbirlerinin yerine kullanıldığı görülmektedir. Birbirlerinden farklı kavramlar olan sosyal yeterlik ve sosyal beceri kavramları, birbirleriyle ilişkili kavramlar olmakla birlikte sosyal yeterlik kavramı sosyal beceri kavramını kapsayan çok boyutlu bir yapı olarak ifade edilmektedir (Merrell ve Gimpel, 1998; Campbell ve Siperstein, 1994; Elliott ve Gresham, 1987; Cavell, 1990; Ergenekon, 2017). Ergenekon'a (2017) göre genel anlamda sosyal yeterlik kavramı; bireyin çevresinde bulunan diğer bireylerle sağliklı ve nitelikli ilişkiler kurabilmesi, yaşadığ çevrede karşılaştığı durumlarla başa çıkabilmesi ve hayatta kalabilmesi noktasında gerekli bilgi ve becerilere sahip olması ve sahip olduğu bu bilgi ve becerileri gerekli yer, durum ve zamanlarda uygun bir şekilde kullanabilmesidir. Zirpoli ve Melloy'a (1997) göre sosyal beceri eksikliği veya sosyal beceri kullanımındaki güçlükler bireylerin sosyal yeterlik gelişimini olumsuz yönde etkileyebilmekte ve dolayısıyla bazı bireylerde sosyal yetersizlikler görülebilmektedir. Sosyal yeterliğin geliştirilmesi noktasında bireylerin çeşitli alanlara ilişkin sosyal becerileri kazanmalarının yanı sıra edinilen sosyal becerilerin uygun zaman ve ortamlarda sergilenmesi gerekliliğinin üzerinde önemle durulmaktadır.

Sosyal yeterliğin bir ögesi olan sosyal beceriler; cinsiyet, yaş, zekâ, dil, tutum, değer, kişilik, yetersizlikten etkilenme durumu, becerilerin kullanıldığı ortam, akran grubu, kitle iletişim araçları, aile ve özellikleri gibi çeşitli değişkenlerden etkilenmektedir (Merrell ve Gimpel, 1998; Olçay Gül, 2018). Ayrıca Elliott ve Gresham (1993) engelleyici problem davranışlar, bilgi, deneyim, geribildirim, ipucu, fırsat ve/veya pekiştirme eksikliği gibi çok sayıda olası değişkenin sosyal yetersizliğe neden olabileceğini ifade etmektedir. Bu bağlamda edinim, performans ve akıcılık yetersizliği şeklinde ortaya çıkabilen sosyal yetersizlik (Gresham, Sugai ve Horner, 2001), gerek yetersizlikten etkilenen gerekse de olağan gelişim özellikleri gösteren tüm bireyler için olası bir durum olarak karşımıza çıkabilmektedir (Begun, 1996; Vuran, 2005). Sosyal yetersizliğin önlenmesi noktasında sosyal becerileri her zaman doğal bir akış içerisinde öğrenemeyen, özel eğitim ihtiyacı olan bireylerin eğitim sürecinde sistematik sosyal beceri öğretimine daha çok önem verilmesi gerekliliğinin üzerinde durulmaktadır (Begun, 1996; Vuran, 2005). Bu görüşlerden de anlaş1lacağ üzere farklı yaşlardaki, farklı potansiyel, fiziksel ve/veya zihinsel gelişim özelliklerine sahip tüm bireylerin toplumsal normların gerektirdiği davranışları yerine getirebilmeleri ve içinde yer aldıkları toplumda etkin ve bağımsız birer birey olabilmeleri noktasında sosyal becerilerin önemi ve gerekliliği üzerinde önemle durulmaktadır.

Konuşmaya katılmak, başlatmak ve devam ettirmek gibi konuşma becerilerini; soru sormak, rica etmek gibi girişkenlik becerilerini; başkaları ile paylaşmak, oyun arkadaşlarını cesaretlendirmek, övgüde bulunmak gibi oyun becerilerini; sakin ve rahat kalmak, olası çözümleri belirlemek ve en iyi seçeneği seçmek gibi problem çözme becerilerini; yönergeleri takip etmek, yapabildiğinin en iyisini yapmak gibi sınıf içi görev davranışlarını; kendine olumlu dönüt vermek, duygularını ifade etmek gibi öz düzenleme becerilerini; kıyafet, davranış vb. açıdan hazırlıklı olmak, özenli olmak gibi iş görüşme becerilerini kapsayan sosyal becerilerin (Mastropieri ve Scruggs, 2000) birçoğu genellikle bireyin diğerleriyle ve çevresiyle etkileşimi sonucunda farkında olmaksızın öğrenilmektedir (Olçay 
Gül, 2018). Başka bir ifadeyle olağan gelişim özellikleri gösteren bireyler pek çok davranış ve cevap türünü kapsayan sosyal becerileri ailelerinin, akranlarının ve diğer yetişkinlerin model olmasıyla ve gözlem yoluyla sistemli olmayan bir öğrenme yöntemiyle farkında olmaksızın öğrenirlerken, akranlarını ve diğer yetişkinleri yeterince gözlemleme olanağına sahip olmayan özel gereksinimli bireyler için bu durum etkileşim yetersizliğinden dolayı çoğunlukla mümkün olamayabilmektedir. Dolayısıyla bu çocuklara sosyal beceriler uygun bir eğitim süreciyle sistemli olarak kazandırılabilinir (Gresham, 1997; Thorkildsen, 1985'den akt. Avcıŏglu, 2012). Özellikle özel gereksinimli bireyler için başarılı bir sosyal, duygusal ve bilişsel gelişim için yaşamsal bir önem taşıyan sosyal beceriler, etkili sosyal beceri öğretim programları dahilinde eğitim programlarının ayrılmaz bir parçası olmalıdır (Bellini, Peters, Benner ve Hopf, 2007). Nitekim bu bağlamda ilgili alanyazında özel eğitim ihtiyacı olan bireylere sosyal becerilerin öğretilmesi ve değerlendirilmesine yönelik olarak doğrudan öğretim, bilişsel süreç yaklaşımı/sosyal problem çözme, kendini yönetme, akran aracılı müdahaleler, sosyal öyküler, video modelle öğretim, firsat öğretimi, yaratıcı drama gibi bireysel ya da grupla uygulanabilecek çeşitli yöntemler yer almaktadır.

Türkiye'de son yıllarda özel eğitim ihtiyacı olan bireylerde sosyal beceri öğretiminin amaçlandığ 1 çeşitli çalışmalar görülmekle birlikte öğretmenlerin ve öğretmen adaylarının sosyal beceri öğretimine ilişkin bilgi düzeylerinin değerlendirilmesine yönelik çalışmaların oldukça sınırlı sayıda olduğu bilinmektedir. İnsanın sağlıklı bir yaşam sürdürebilmesi, içinde bulunduğu fiziksel ve sosyal çevreye uyum sağlayabilmesine bağlıdır. Bu nedenle sosyal gelişim ve buna bağlı olarak sosyal beceri kavramı büyük bir önem taşımaktadır. Sosyalleşme süreci içinde örnek alınan modellerin başında gelmekte olan öğretmenlerin, sosyal gelişim ve sosyal beceri öğretim sürecini iyi bilmeleri gerekmektedir (Selçuk, 2012). Çünkü çocuğun evi dışında en çok zaman geçirdiği okul ortamları çocuğun sosyal gelişiminde oldukça etkili ve önemli görülmektedir. Dolayısıyla sosyal beceri kazandırma sorumluluğu çocuğun okula başlamasıyla aileden, öğretmene geçmektedir. Öğretici ve sosyalleştirici olmak üzere iki temel rolü bulunan öğretmenlerin sosyalleştirici rolü özellikle okul öncesi ve ilkokul dönemlerinde büyük bir önem kazanmaktadır (Meşeci, 2008). Nitekim bu bağlamda sosyal beceri öğretiminin ailelerin yanı sıra öğretmenlerin de sorumluluğunda olduğu düşüncesinden hareketle bu araştırmada sınıfında özel gereksinimli öğrenci bulunan sınıf öğretmenleri ile sınıf öğretmeni adaylarının sosyal beceri öğretimine ilişkin bilgi düzeylerinin çeşitli değişkenler açısından incelenmesi ve karşılaştırılması amaçlanmıştır. Bu amaç doğrultusunda araştırma kapsamında aşağıdaki sorulara yanıt aranmıştır.

\section{Araştırma Soruları:}

Sınıf öğretmenleri ile sınıf öğretmenliği öğretmen adaylarının sosyal beceri öğretimine ilişkin bilgi düzeylerinin incelenmesi ve karşılaştırılması amacıyla yapılan bu araştırmada aşağıdaki sorulara cevap aranmaya çalışılmıştır;

1. Sınıf öğretmenleri ile sınıf öğretmeni adaylarının sosyal beceri öğretimine ilişkin bilgi düzeyleri nedir?

2. Sınıf öğretmenleri ile sınıf öğretmeni adaylarının sosyal beceri öğretimine ilişkin bilgi düzeyleri arasında anlamlı bir farklılık var mıdır?

3. Sınıf öğretmenleri ile sınıf öğretmeni adaylarının sosyal beceri öğretimine ilişkin bilgi düzeyleri cinsiyet değişkeni bakımından farklılaşmakta mıdır?

4. Sınıf öğretmenleri ile sınıf öğretmeni adaylarının sosyal beceri öğretimine ilişkin bilgi düzeyleri yaş değişkeni bakımından farklılaşmakta mıdır?

5. Sınıf öğretmeni adaylarının sosyal beceri öğretimine ilişkin bilgi düzeyleri mezun olunan lise türü değişkenine göre farklılaşmakta mıdır? 
6. Sınıf öğretmenlerinin sosyal beceri öğretimine ilişkin bilgi düzeyleri mezun olunan üniversite bölümü değişkenine göre farklılaşmakta mıdır?

7. Sınıf öğretmenlerinin sosyal beceri öğretimine ilişkin bilgi düzeyleri mesleki hizmet yılı değişkenine göre farklılaşmakta mıdır?

\section{Yöntem}

$\mathrm{Bu}$ bölümde araştırma grubu, araştırma modeli, veri toplama araçları ve verilerin analizinde kullanılan istatistiksel teknikler açıklanmıştır.

\section{Araștırma Grubu}

Araştırmada 2 ayrı örneklem kullanılmıştır. Bu örneklem gruplarına ilişkin ayrıntılı bilgiler aşağıda verilmiştir.

\section{Örneklem 1}

Araştırmanın amacına bağlı olarak, bilgi açısından zengin durumların seçilmesiyle birlikte derinlemesine bir araştırmanın yapılmasına olanak sağlayan amaçsal örnekleme yöntemine başvurularak sınıfında özel gereksinimli öğrenci bulunan 61 sınıf öğretmeni araştırmaya dahil edilmiştir. Amaçsal örnekleme seçkisiz olmayan bir örnekleme yaklaşımı olup genellikle belirli ölçütleri karşılayan veya belirli özelliklere sahip olan bir veya daha fazla özel durumlarda çalışılmak istenildiğinde tercih edilir (Büyüköztürk, Kılıç Çakmak, Akgün, Karadeniz ve Demirel, 2016). Bu yöntemin esası popülasyondan bilgi edinmek istenen özelliği içeren elemanları araştırmaya dahil etmektir (Arlı ve Nazik, 2004). Bilindiği üzere amaçsal örnekleme yöntemi aykırı örnekleme, maksimum çeşitlilik örnekleme, benzeşik örnekleme, tipik durum örnekleme, tabakalı amaçsal örnekleme ve ölçüt örnekleme yöntemleri gibi çeşitli örnekleme yöntemlerinden oluşmaktadır. Araştırmanın amacı doğrultusunda bu farklı örnekleme yöntemlerinden gözlem birimlerinin belli niteliklere sahip kişiler, olaylar, nesneler ya da durumlardan oluşması durumunda başvurulan ölçüt örnekleme yöntemine başvurulmuştur (Büyüköztürk ve diğerleri, 2016).

\section{Örneklem 2}

Sınıf öğretmenleri adaylarının araştırmaya dahil edilmesinde zaman, para ve işgücü kaybını önlemeyi temel amaç edinen uygun örnekleme yöntemi (Büyüköztürk ve diğerleri, 2016) tercih edilmiş olup, ulaşılabilecek en üst sayıdaki katılımcıya ulaşılmaya çalışılmıştır. Bu amaç doğrultusunda Kafkas Üniversitesi Dede Korkut Eğitim Fakültesi'nde 2018-2019 eğitim-öğretim yılında son sınıfta öğrenim gören 81 sınıf öğretmeni adayına ulaşılımıştır.

Araştırmaya katılan sınıf öğretmenleri ile sınıf öğretmeni adaylarının demografik özellikleri Tablo 1, 2, 3, 4, 5 ve 6'da sunulmuştur.

Araştırma Grubundaki Katılımcıların Demografik Özellikleri

Tablo 1: Katılımcıların Frekans ve Yüzde Değerleri

\begin{tabular}{ccccc}
\hline Katılımcılar & f & \% & Geçerli \% & Yı̆̆ılmalı \% \\
\hline Ö̆ğretmen & 61 & 43.0 & 43.0 & 43.0 \\
Öğretmen Adayı & 81 & 57.0 & 57.0 & 100.0 \\
\hline Toplam & 142 & 100.0 & 100.0 & \\
\hline
\end{tabular}

Tablo 1 incelendiğinde, araştırma grubunun 61'i (\%43.0) öğretmen; 81'i (\%57,0) öğretmen adayı olmak üzere toplam 142 katılımcıdan oluştuğu gözlenmektedir. 
Sınıf Öğretmenleri ile Sınıf Öğretmeni Adaylarının Sosyal Beceri Öğretimine İlişkin Bilgi... 1107

\begin{tabular}{ccccc}
\hline \multicolumn{5}{c}{ Tablo 2: Cinsiyet Değişkeni İçin Frekans ve Yüzde Değerleri } \\
\hline Cinsiyet & f & \% & Geçerli \% & Yı̆̆ılmalı \% \\
\hline Kadın & 96 & 67.6 & 67.6 & 67.6 \\
Erkek & 46 & 32.4 & 32.4 & 100.0 \\
\hline Toplam & 142 & 100.0 & 100.0 & \\
\hline
\end{tabular}

Tablo 2 incelendiğinde, araştırma grubunun 96's1 (\%67.6) kadın; 46's1 (\%32.4) erkek olmak üzere toplam 142 katılımcıdan oluştuğu gözlenmektedir.

Tablo 3: Yaş Değişkeni İçin Frekans ve Yüzde Değerleri

\begin{tabular}{ccccc}
\hline Yaș & f & \% & Geçerli \% & Yığılmalı \% \\
\hline 25 ve altı & 80 & 56.3 & 56.3 & 56.3 \\
$\mathbf{2 6 - 3 5}$ & 18 & 12.7 & 12.7 & 69.0 \\
$\mathbf{3 6 - 4 5}$ & 31 & 21.8 & 21.8 & 90.8 \\
46 ve üstü & 13 & 9.2 & 9.2 & 100.0 \\
\hline Toplam & 142 & 100.0 & 100.0 & \\
\hline
\end{tabular}

Tablo 3 incelendiğinde, araştırma grubunu oluşturan katılımcıların 80'inin (\%56.3) 25 ve altı; 18'inin (\%12.7) 26-35; 31 'inin (\%21.8) 36-45; 13'ünün (\%9.2) ise 46 ve üstü yaş aralığında yer aldığ 1 görülmektedir.

Tablo 4: Mezun Olunan Lise Türü Değişkeni İçin Frekans ve Yüzde Değerleri

\begin{tabular}{ccccc}
\hline MOLT & f & \% & Geçerli \% & Yiğılmalı \% \\
\hline AL & 31 & 38.3 & 38.3 & 38.3 \\
ÖL & 3 & 3.7 & 3.7 & 42.0 \\
MTAL & 6 & 7.4 & 7.4 & 49.4 \\
Aं̈HL & 1 & 1.2 & 1.2 & 50.6 \\
DL & 31 & 38.3 & 38.3 & 88.9 \\
Diğer & 9 & 11.1 & 11.1 & 100.0 \\
\hline Toplam & 81 & 100.0 & 100.0 & \\
\hline
\end{tabular}

Kisaltmalar: MOLT: Mezun Olunan Lise Türü, AL: Anadolu Lisesi, ÖL: Öğretmen Lisesi, MTAL: Mesleki ve Teknik Anadolu Lisesi, AIHL: Anadolu Imam Hatip Liseleri, DL: Düz Lise

Tablo 4 incelendiğinde, araştırma grubunu oluşturan sınıf öğretmeni adaylarının 31'inin (\%38.3) anadolu lisesinden; 3'ünün (\%3.7) öğretmen lisesinden; 6'sının (\%7.4) mesleki ve teknik anadolu lisesinden; 1'inin (\%1.2) anadolu imam hatip lisesinden; 31'inin (\%38.3) düz liseden, 9'unun (\%11.1) ise diğer lise türünden mezun oldukları görülmektedir.

Tablo 5: Mezun Olunan Üniversite Bölümü Değișkeni İçin Frekans ve Yüzde Değerleri

\begin{tabular}{ccccc}
\hline $\begin{array}{c}\text { Mezun Olunan } \\
\text { Üniversite } \\
\text { Bölümü }\end{array}$ & f & \% & Geçerli \% & Yığılmalı \% \\
\hline $\begin{array}{c}\text { Sinıf } \\
\text { Öğretmenliği } \\
\quad \text { Branş }\end{array}$ & 47 & 77.0 & 77.0 & 77.0 \\
$\begin{array}{c}\text { Öğretmenliği } \\
\text { Diğer }\end{array}$ & 8 & 13.1 & 13.1 & 90.2 \\
\hline Toplam & 6 & 9.8 & 9.8 & 100.0 \\
\hline
\end{tabular}

Tablo 5 incelendiğinde, araştırma grubunu oluşturan sınıf öğretmenlerinin 47'sinin (\%77.0) sınıf öğretmenliği; 8'inin (\%13.1) branş öğretmenliğgi; 6'sının (\%7.4) ise öğretmenlik bölümü haricindeki diğer üniversite bölümlerinden mezun oldukları görülmektedir. 


\begin{tabular}{ccccc}
\hline \multicolumn{5}{c}{ Tablo 6: Mesleki Hizmet Yilı Değişkeni İçin Frekans ve Yüzde Değerleri } \\
\hline $\begin{array}{c}\text { Mesleki Hizmet } \\
\text { Yllı }\end{array}$ & $\mathbf{f}$ & $\mathbf{\%}$ & Geçerli \% & Yığılmalı \% \\
\hline $\mathbf{0 - 1 0}$ & 10 & 16.4 & 16.4 & \\
$\mathbf{1 1 - 2 0}$ & 34 & 55.7 & 55.7 & 76.4 \\
$\mathbf{2 1 - 3 0}$ & 15 & 24.6 & 24.6 & 96.1 \\
$\mathbf{3 1 ~ v e ~ u ̈ s t u ̈ ~}$ & 2 & 3.3 & 3.3 & 100.0 \\
\hline Toplam & 61 & 100.0 & 100.0 & \\
\hline
\end{tabular}

Tablo 6 incelendiğinde, araştırma grubunu oluşturan sınıf öğretmenlerinin 10'unun (\%16.4) 0-10 yıl; 34'ünün (\%55.7) 11-20 yıl; 15'inin (\%24.6) 21-30 yıl; 2'sinin (\%3.3) ise 31 ve üstü mesleki hizmet süresine sahip oldukları görülmektedir.

\section{Araştırma Modeli}

Sınıfında özel gereksinimli öğrenci bulunan sınıf öğretmenleri ile sınıf öğretmenliği öğretmen adaylarının sosyal beceri öğretimine ilişkin bilgi düzeylerinin çeşitli değişkenler açısından incelendiği bu araştırmada, tarama (betimsel, survey) modelinden yararlanılmıştır. Tarama araştırmaları, bir konuya ya da olaya ilişkin katılımcıların görüşlerinin ya da inanç, bilgi, kaygı, ilgi, beceri, yetenek, tutum vb. özelliklerinin belirlendiği genellikle diğer araştırmalara göre daha büyük örneklemler üzerinde yapılan araştırmalardır. Geniş kitlelerin görüşlerini, özelliklerini olduğu gibi betimlemeyi amaçlayan tarama araştırmaları, "neden" sorusundan ziyade "ne, nerede, ne zaman, hangi sıklıkta, hangi düzeyde, nasıl" gibi soruların yanıt bulmasına olanak tanımaktadır. Bir grubun belirli özelliklerini belirlemek için verilerin toplanmasını amaçlayan tarama araştırmaları, farklı şekillerde sınıflandırılabilmektedir (Büyüköztürk ve diğerleri, 2016). Bu araştırma kapsamında ise evren hakkında genel bir yargıya ulaşılması amacıyla genel tarama modelinin kullanılması uygun görülmüştür (Karasar, 2012).

\section{Veri Toplama Araçları}

Araştırmada gerekli olan verilerin toplanması amacıyla araştırmacı tarafından oluşturulan "Kişisel Bilgi Formu (KBF)" ve Sazak Pınar (2009) tarafından geliştirilen "Sosyal Beceri Öğretimi Bilgi Testi (SBÖBT)" kullanılmıştır.

\section{Kişisel Bilgi Formu (KBF):}

Sınıf öğretmenlerine yönelik oluşturulan Kişisel Bilgi Formu'nda cinsiyet, yaş, mezun olunan üniversite bölümü ve mesleki hizmet süresine ilişkin 4 soru yer alırken, öğretmen adaylarına yönelik oluşturulan Kişisel Bilgi Formu'nda cinsiyet, yaş ve mezun olunan lise türüne ilişkin 3 soru yer almaktadır.

\section{Sosyal Beceri Öğretimi Bilgi Testi (SBÖBT):}

Öğretmenlerin sosyal beceri öğretimine ilişkin bilgi düzeylerini belirlemek amaciyla Sazak Pınar (2009) tarafından geliştirilen, iki bölümden oluşan SBÖBT'i kullanılmıştır. SBÖBT'nin birinci bölümünde öğretmenlerin sosyal beceri kavramına, öğretim yöntem ve tekniklerine ilişkin problem durumlarına yönelik 13 çoktan seçmeli soru yer alırken, ikinci bölümünde 5 kısa cevaplı soru olmak üzere toplam 18 soru yer almaktadır (Sazak Pınar, 2009). Çoktan seçmeli sorularda her doğru cevap 1 , kısa cevaplı sorularda ise 0-2 arasında puanlanmaktadır. SBÖBT'ten alınabilecek en yüksek puan 23 iken, en düşük puan 0'dır. SBÖBT’ten alınan puanların artması sosyal beceri öğretimine ilişkin bilgi düzeylerinin yüksek olduğunu, azalması ise sosyal beceri öğretimine ilişkin bilgi düzeylerinin düşük olduğunu göstermektedir (Sazak Pınar, Sucuoğlu ve Çıkrıkçı Demirtaşl1, 2013).

SBÖBT'nin kapsam geçerliği 2'si ölçme değerlendirme alanında, 6'sı özel eğitim ve sosyal beceri eğitimi konusunda çalışan kişiler olmak üzere toplam 8 uzman görüşü doğrultusunda gerçekleştirilirken, SBÖBT'deki her bir maddeye yönelik uzman değerlendirmelerin ortalaması, 
standart sapması ve değişim katsayısı hesaplanmıştır. Yapılan bu hesaplamalar doğrultusunda SBÖBT'den hiçbir maddenin çıkarılmaması sonucuna ulaşılmış olup, uzman önerileri doğrultusunda madde ve seçeneklerinde düzeltmeler yapılmıştır (Sazak Pınar, 2012).

SBÖBT'nin güvenirlik çalışması ise çalışma grubuna dahil edilmeyen, sınıfında özel gereksinimli öğrenci bulunan toplam 450 öğretmenin maddelere vermiş olduğu yanıtlar üzerinden madde analizi yapılarak gerçekleştirilmiştir. Yapılan bu güvenirlik çalışması sonucunda 18 madde testten çıkarılmıştır. Geriye kalan çoktan seçmeli 13 maddenin 4'ünün zor, 4'ünün orta ve 5'inin kolay düzeyde madde olduğu, madde güçlüklerinin teste eşit oranda dağıldığ maddelerin ayırıcılık gücünün iyi düzeyde olduğu belirlenmiştir. SBÖBT'nin KR-20, güvenirlik katsayısı ise .78 bulunmuştur (Sazak Pınar, 2012).

\section{Verilerin Analizi}

Araştırmadan elde edilen nicel verilerin anlamlı hale getirilmesi aşamasında öncelikle toplanan form ve testler araştırmacı tarafından kontrol edilerek eksik ve/veya yanlış doldurulanlar araştırma dışında tutulmuş, geçerli ve kabul edilebilir nitelikte olanlar ise SPSS 24 (Statistical Package for Social Scientists for Windows Release) paket programında değerlendirilmek üzere kodlanarak bilgisayar ortamına aktarılmıştır.

KBF'den elde edilen verilerinin anlamlı hale getirilmesi aşamasında yalnızca betimsel istatistiklerden (frekans dağılımları, merkezi eğilim ve değişkenlik ölçüleri) yararlanılırken, SBÖBT'ten elde edilen verilerin anlamlı hale getirilmesi aşamasında ise betimsel istatistiklerin yanı sıra anlam çıkartıcı istatistiklerden de yararlanılmıştır. Bu bağlamda uygun anlam çıkartıcı istatistik tekniğinin belirlenmesi aşamasında öncelikle her bir değişkene ait dağılımın normalliğini denetlemek için gerekli olan ön analizler (Shapiro-Wilk, Kolmogrov-Smirnov ve Çarpıklık-Basıklık değerlerinin incelenmesi) yapılmış ve yapılan bu analizler sonucunda veri setlerinin normal dağılım göstermedikleri gözlenmiş olup non-parametrik testler kullanılmıştır. Bu doğrultuda öğretmen ve öğretmen adaylarının sosyal beceri öğretimine ilişkin bilgi düzeylerinin cinsiyet değişkenine göre anlamlı bir şekilde farklılaşıp farklılaşmadığını belirlemek üzere non-parametrik Mann Whitney U testi uygulanırken; bilgi düzeylerinin yaş, mesleki hizmet süresi, mezun olunan lise türü ve üniversite bölümü değişkenlerine göre anlamlı bir şekilde farklılaşıp farklılaşmadığını belirlemek üzere ise Kruskal Wallis H testi uygulanmıştır. Son olarak, aritmetik ortalama değerleri yorumlanmasında 0 7.6 (düşük düzey), 7.7 - 15.3 (orta düzey), 15.4 - 23.0 (yüksek düzey) aralıkları baz alınmıştır.

\section{Bulgular}

Sınıf öğretmenleri ile sınıf öğretmeni adaylarının sosyal beceri öğretimine ilişkin bilgi düzeylerinin belirlenmesini ve çeşitli değişkenler açısından incelenmesini amaçlayan araştırmanın bu bölümünde elde edilen bulgular, araştırmanın alt problemleri doğrultusunda sunulmuştur.

\section{Birinci Araştırma Sorusuna Yönelik Bulgular}

Sınıf öğretmenleri ile sınıf öğretmeni adaylarının sosyal beceri öğretimine ilişkin bilgi düzeyleri nedir? sorusuna yönelik bulgular Tablo 7 ve 8 'de sunulmuştur.

Tablo 7: Sınıf öğretmenlerinin SBÖBT’ten Aldıkları Puanlara İlişkin Betimsel İstatistikler

\begin{tabular}{cccccccc}
\hline & $\overline{\mathbf{X}}$ & Ortanca & Ss & Min. & Max. & Çarpıklık & Basıklık \\
\hline B1 & 8.30 & 8.00 & 2.10 & 2.00 & 13.00 & -.506 & 918 \\
B2 & 3.30 & 4.00 & .92 & .00 & 5.00 & -1.164 & 1.669 \\
T & 11.60 & 12.00 & 2.20 & 5.00 & 17.00 & -.454 & 1.259 \\
\hline
\end{tabular}

Kısaltmalar: B1: Bölüm 1 (Çoktan Seçmeli Sorular); B2: Bölüm 2 (Kısa Cevapl Sorular) T: Toplam (Test Geneli) 
Tablo 7'de görüldüğü gibi, sınıf öğretmenlerinin SBÖBT'nin birinci bölümü olan çoktan seçmeli sorulardan aldıkları puanların ortalaması $\bar{X}=8.30$, kısa cevaplı sorulardan oluşan ikinci bölümden aldıkları puanların ortalaması ise $\overline{\mathrm{X}}=3.30$ 'dur. Test genelinden alınan en düşük puan Min. $=5.00$, en yüksek puan Max. $=17.00$, standart sapma ise $\mathrm{Ss}=2.20$ olarak belirlenmiştir. SBÖBT'ten alınacak en yüksek puan Max.=23.00'tür, ancak araştırmaya katılan sınıf öğretmenleri testten ortalama $\bar{X}=11.60$ puan almışlardır. $\mathrm{Bu}$ durumda sınıf öğretmenlerinin sosyal beceri öğretimine ilişkin bilgi düzeylerinin orta düzeyde (0 - 7.6 düşük düzey, 7.7 - 15.3 orta düzey, 15.4 23.0 yüksek düzey) olduğu söylenebilir.

Tablo 8: Sınıf öğretmeni adaylarının SBÖBT’ten Aldıkları Puanlara İlişkin Betimsel İstatistikler

\begin{tabular}{cccccccc}
\hline & $\overline{\mathbf{X}}$ & Ortanca & Ss & Min. & Max. & Çarpıklık & Basıklık \\
\hline B1 & 8.72 & 9.00 & 1.55 & 4.00 & 12.00 & -.560 & .692 \\
B2 & 3.10 & 3.00 & 1.07 & .00 & 5.00 & -1.257 & 1.203 \\
T & 11.81 & 12.00 & 1.93 & 4.00 & 15.00 & -1.472 & 5.005 \\
\hline
\end{tabular}

Tablo 8'de görüldüğ̈̈ gibi, sınıf öğretmeni adaylarının SBÖBT'nin birinci bölümü olan çoktan seçmeli sorulardan aldıkları puanların ortalaması $\bar{X}=8.72$, kısa cevaplı sorulardan oluşan ikinci bölümden aldıkları puanların ortalaması ise $\bar{X}=3.10$ 'dur. Test genelinden alınan en düşük puan Min.=4.00, en yüksek puan Max.=15.00, standart sapma ise $\mathrm{Ss}=1.93$ olarak belirlenmiştir. SBÖBT'ten alınacak en yüksek puan Max. $=23.00$ 'tür, ancak araştırmaya katılan sınıf öğretmeni adayları testten ortalama $\overline{\mathrm{X}}=11.81$ puan almışlardır. Bu durumda sınıf öğretmeni adaylarının sosyal beceri öğretimine ilişkin bilgi düzeylerinin orta düzeyde olduğu söylenebilir.

\section{İkinci Araştırma Sorusuna Yönelik Bulgular}

Sınıf öğretmenleri ile sınıf öğretmeni adaylarının sosyal beceri öğretimine ilişkin bilgi düzeyleri arasında anlamlı bir farklılık var mıdır? sorusuna yönelik bulgular Tablo 9'da sunulmuştur.

Tablo 9: SBÖBT’ten Alınan Puanların Öğretmen ve Öğretmen Adayı Olma Durumuna Göre Mann Whitney U-Testi Sonuçları

\begin{tabular}{ccccccc}
\hline & & $\mathbf{n}$ & $\begin{array}{c}\text { Sira } \\
\text { Ortalaması }\end{array}$ & $\begin{array}{c}\text { Sira } \\
\text { Toplamı }\end{array}$ & $\mathbf{U}$ & $\mathbf{p}$ \\
\hline \multirow{3}{*}{ B1 } & SÖ & 61 & 66.47 & 4054.50 & & \\
& SÖA & 81 & 75.29 & 6098.50 & 2163.500 & .198 \\
& Toplam & 142 & & & & \\
\hline \multirow{3}{*}{ B2 } & SÖ & 61 & 74.30 & 4532.50 & & \\
& SÖA & 81 & 69.39 & 5620.50 & 2299.500 & .449 \\
& Toplam & 142 & & & & \\
\multirow{2}{*}{ T } & SÖ & 61 & 68.56 & 4182.00 & & \\
& SÖA & 81 & 73.72 & 5971.00 & 2291.500 & .452 \\
& Toplam & 142 & & & & \\
\hline
\end{tabular}

Kısatmalar: SÖ: Sinıf Öğretmeni; SÖA: Sinlf Öğretmeni Adayı

Tablo 9'da yer alan SBÖBT'nin genelinden alınan toplam puan incelendiğinde, sınıf öğretmenleri ile sınıf öğretmeni adaylarının sosyal beceri öğretimine ilişkin bilgi düzeylerinin birbirlerinden anlamlı düzeyde farklılaşmadığı anlaşılmaktadır. 
Sınıf Öğretmenleri ile Sınıf Öğretmeni Adaylarının Sosyal Beceri Öğretimine İlişkin Bilgi... 1111

\section{Üçüncü Araştırma Sorusuna Yönelik Bulgular}

Sınıf öğretmenleri ile sınıf öğretmeni adaylarının sosyal beceri öğretimine ilişkin bilgi düzeyleri cinsiyet değişkeni bakımından farklılaşmakta mıdır? sorusuna yönelik bulgular Tablo 10 ve 11 'de sunulmuştur.

Tablo 10: Cinsiyet Değişkenine Göre SBÖBT’ten Alınan Puanlara İlişkin Betimsel İstatistikler

\begin{tabular}{ccccccccc}
\hline & & $\overline{\mathbf{X}}$ & Ortanca & Ss & Min. & Max. & Çarpıklık & Basıklık \\
\hline \multirow{4}{*}{ Kadın } & $\boldsymbol{B 1}$ & 8.66 & 8.50 & 1.65 & 4.00 & 13.00 & -.066 & .085 \\
& $\boldsymbol{B} 2$ & 3.32 & 4.00 & .98 & .00 & 5.00 & -1.518 & 2.746 \\
& $\boldsymbol{T}$ & 11.98 & 12.00 & 1.76 & 7.00 & 17.00 & .020 & .465 \\
\hline \multirow{3}{*}{ Erkek } & $\boldsymbol{B 1}$ & 8.28 & 9.00 & 2.12 & 2.00 & 12.00 & -.1 .067 & 1.356 \\
& $\boldsymbol{B 2}$ & 2.89 & 3.00 & 1.20 & .00 & 5.00 & -.921 & .439 \\
& $\boldsymbol{T}$ & 11.17 & 12.00 & 2.48 & 4.00 & 15.00 & -.1 .397 & 2.306 \\
\hline
\end{tabular}

Tablo 10 incelendiğinde, kadın sınıf öğretmenleri ile sınıf öğretmeni adayları tarafından alınan test geneli puanların aritmetik ortalaması $\bar{X}=11.98$ olarak, erkek sınıf öğretmenleri ile sınıf öğretmeni adayları tarafından alınan test geneli puanların aritmetik ortalaması $\bar{X}=11.17$ olarak hesaplanmıştır.

Tablo 11: Sınıf Öğretmenleri ile Sınıf Öğretmeni Adaylarının SBÖBT’ten Aldıkları Puanların Cinsiyet Değişkenine Göre Mann Whitney U-Testi Sonuçları

\begin{tabular}{ccccccc}
\hline & & $\mathbf{n}$ & $\begin{array}{c}\text { Sira } \\
\text { Ortalaması }\end{array}$ & $\begin{array}{c}\text { Sira } \\
\text { Toplamı }\end{array}$ & $\mathbf{U}$ & $\mathbf{p}$ \\
\hline \multirow{3}{*}{ B1 } & Kadın & 96 & 72.54 & 6963.50 & & \\
& Erkek & 46 & 69.34 & 3189.50 & 2108.500 & .659 \\
& Toplam & 142 & & & & \\
\hline \multirow{3}{*}{ B2 } & Kadın & 96 & 76.56 & 7350.00 & & \\
& Erkek & 46 & 60.93 & 2803.00 & 1722.000 & .023 \\
& Toplam & 142 & & & & \\
\hline \multirow{2}{*}{$\mathbf{T}$} & Kadın & 96 & 68.56 & 7190.00 & & \\
& Erkek & 46 & 73.72 & 2963.00 & 1882.000 & .148 \\
& Toplam & 142 & & & & \\
\hline
\end{tabular}

Tablo 11'de yer alan SBÖBT'nin genelinden alınan toplam puan incelendiğinde, sınıf öğretmenleri ile sınıf öğretmeni adaylarının sosyal beceri öğretimine ilişkin bilgi düzeylerinin cinsiyet değişkeni açısından anlamlı düzeyde farklılaşmadığı görülmektedir.

\section{Dördüncü Araştırma Sorusuna Yönelik Bulgular}

Sınıf öğretmenleri ile sınıf öğretmeni adaylarının sosyal beceri öğretimine ilişkin bilgi düzeyleri yaş değişkeni bakımından farklılaşmakta mıdır? sorusuna yönelik bulgular Tablo 12 ve 13 ’te sunulmuştur. 
Tablo 12: Yaş Değişkenine Göre SBÖBT’ten Alınan Puanlara İlişkin Betimsel İstatistikler

\begin{tabular}{ccccccccc}
\hline & & $\overline{\mathbf{X}}$ & Ortanca & Ss & Min. & Max. & Çarpıklık & Basıklık \\
\hline \multirow{2}{*}{ 25 ve altı } & $\boldsymbol{B} 1$ & 8.77 & 9.00 & 1.47 & 4.00 & 12.00 & -.364 & .302 \\
& $\boldsymbol{B} 2$ & 3.13 & 3.00 & 1.12 & .00 & 5.00 & -1.256 & 1.423 \\
& $\boldsymbol{T}$ & 11.90 & 12.00 & 1.73 & 4.00 & 15.00 & -1.040 & 4.237 \\
\hline \multirow{2}{*}{$\mathbf{2 6 - 3 5}$} & $\boldsymbol{B 1}$ & 8.56 & 9.00 & 2.01 & 4.00 & 11.00 & -.583 & -.098 \\
& $\boldsymbol{B} 2$ & 3.11 & 3.00 & 1.08 & .00 & 4.00 & -1.509 & 2.782 \\
& $\boldsymbol{T}$ & 11.67 & 12.00 & 2.63 & 4.00 & 15.00 & -1.460 & 3.290 \\
\hline \multirow{3}{*}{$\mathbf{3 6 - 4 5}$} & $\boldsymbol{B 1}$ & 8.26 & 8.00 & 2.11 & 2.00 & 13.00 & -.431 & 1.865 \\
& $\boldsymbol{B} 2$ & 3.19 & 3.00 & 1.01 & .00 & 4.00 & -1.440 & 2.133 \\
& $\boldsymbol{T}$ & 11.45 & 11.00 & 2.11 & 6.00 & 17.00 & -.144 & 1.884 \\
\hline \multirow{4}{*}{ 46 ve üzeri } & $\boldsymbol{B} \mathbf{2}$ & 7.69 & 8.00 & 2.50 & 3.00 & 12.00 & -.422 & .077 \\
& $\boldsymbol{T}$ & 11.31 & 12.00 & 2.84 & 5.00 & 16.00 & -.704 & .942 \\
\hline
\end{tabular}

Tablo 12 incelendiğinde, 25 ve altı yaș grubunda yer alan sınıf öğretmenleri ile sınıf öğretmeni adaylarının test geneli puanların aritmetik ortalaması $\bar{X}=11.90$ olarak, 26-35 yaş grubunda $\overline{\mathrm{X}}=11.67,36-45$ yaş grubunda $\overline{\mathrm{X}}=11.45,46$ ve üzeri yaş grubunda ise $\overline{\mathrm{X}}=11.31$ olarak hesaplanmıştır.

Tablo 13: Sınıf Öğretmeni ile Sınıf Öğretmeni Adaylarının SBÖBT’ten Aldıkları Puanların Yaş Değișkenine Göre Kruskal Wallis H-Testi Sonuçları

\begin{tabular}{|c|c|c|c|c|c|c|}
\hline & & $\mathbf{n}$ & $\begin{array}{c}\text { Sira } \\
\text { Ortalaması }\end{array}$ & sd & $\mathbf{X}^{2}$ & $\mathbf{p}$ \\
\hline \multirow{5}{*}{ B1 } & 25 ve altı & 80 & 76.18 & \multirow{5}{*}{3} & \multirow{5}{*}{3.70} & \multirow{5}{*}{.296} \\
\hline & 26-35 & 18 & 73.25 & & & \\
\hline & $36-45$ & 31 & 64.44 & & & \\
\hline & 46 ve üzeri & 13 & 57.12 & & & \\
\hline & Toplam & 142 & & & & \\
\hline \multirow{5}{*}{ B2 } & 25 ve altı & 80 & 69.51 & \multirow{5}{*}{3} & \multirow{5}{*}{2.72} & \multirow{5}{*}{.437} \\
\hline & 26-35 & 18 & 68.39 & & & \\
\hline & $36-45$ & 31 & 71.55 & & & \\
\hline & 46 ve üzeri & 13 & 87.92 & & & \\
\hline & Toplam & 142 & & & & \\
\hline \multirow{5}{*}{$\mathbf{T}$} & 25 ve altı & 80 & 74.28 & \multirow{5}{*}{3} & \multirow{5}{*}{1.66} & \multirow{5}{*}{.646} \\
\hline & 26-35 & 18 & 74.81 & & & \\
\hline & $36-45$ & 31 & 64.18 & & & \\
\hline & 46 ve üzeri & 13 & 67.27 & & & \\
\hline & Toplam & 142 & & & & \\
\hline
\end{tabular}

Tablo 13'te yer alan SBÖBT'nin genelinden alınan toplam puan incelendiğinde, sınıf öğretmenleri ile sınıf öğretmeni adaylarının sosyal beceri öğretimine ilişkin bilgi düzeylerinin yaş değişkeni açısından anlamlı düzeyde farklılaşmadığı görülmektedir.

\section{Beşinci Araştırma Sorusuna Yönelik Bulgular}

Sınıf öğretmeni adaylarının sosyal beceri öğretimine ilişkin bilgi düzeyleri mezun olunan lise türü değişkenine göre farklılaşmakta mıdır? sorusuna yönelik bulgular Tablo 14 ve $15^{\text {'te }}$ sunulmuştur. 
Sınıf Öğretmenleri ile Sınıf Öğretmeni Adaylarının Sosyal Beceri Öğretimine İlişkin Bilgi... 1113

Tablo 14: Mezun Olunan Lise Türü Değişkenine Göre SBÖBT’ten Alınan Puanlara İlişkin Betimsel İstatistikler

\begin{tabular}{ccccccccc}
\hline & & $\overline{\mathbf{X}}$ & Ortanca & Ss & Min. & Max. & Çarpılklı & Basıklık \\
\hline \multirow{4}{*}{ AL } & $\boldsymbol{B 1}$ & 8.87 & 9.00 & 1.36 & 6.00 & 11.00 & -.176 & -.658 \\
& $\boldsymbol{B 2}$ & 3.23 & 4.00 & 1.18 & .00 & 5.00 & -1.525 & 2.250 \\
& $\boldsymbol{T}$ & 12.10 & 12.00 & 1.58 & 9.00 & 15.00 & -.061 &.-479 \\
\hline \multirow{3}{*}{ ÖL } & $\boldsymbol{B 1}$ & 8.33 & 8.00 & .58 & 8.00 & 9.00 & -.573 & 1.732 \\
& $\boldsymbol{B 2}$ & 3.33 & 3.00 & .58 & 3.00 & 4.00 & 1.732 & - \\
& $\boldsymbol{T}$ & 11.67 & 12.00 & .58 & 11.00 & 12.00 & -.1 .732 & - \\
\hline \multirow{4}{*}{ MTAL } & $\boldsymbol{B 1}$ & 8.50 & 8.00 & 1.22 & 7.00 & 10.00 & -.490 & -1.467 \\
& $\boldsymbol{B 2}$ & 3.17 & 3.00 & .75 & 2.00 & 4.00 & -.313 & -.104 \\
& $\boldsymbol{T}$ & 11.67 & 11.50 & 1.37 & 10.00 & 14.00 & .889 & 1.339 \\
\hline \multirow{3}{*}{ DL } & $\boldsymbol{B 1}$ & 9.10 & 9.00 & 1.61 & 4.00 & 12.00 & -.878 & .1 .865 \\
& $\boldsymbol{B 2}$ & 3.00 & 3.00 & 1.24 & .00 & 5.00 & -1.013 & .589 \\
& $\boldsymbol{T}$ & 12.06 & 12.00 & 2.08 & 4.00 & 15.00 & -1.872 & 6.420 \\
\hline \multirow{2}{*}{ Diğer } & $\boldsymbol{B 1}$ & 7.11 & 7.00 & 1.62 & 4.00 & 9.00 & -.685 & .278 \\
& $\boldsymbol{B} 2$ & 2.89 & 3.00 & 1.45 & .00 & 4.00 & -1.329 & .746 \\
& $\boldsymbol{T}$ & 10.0 & 11.00 & 2.45 & 4.00 & 12.00 & -2.165 & 5.339 \\
\hline
\end{tabular}

Tablo 14 incelendiğinde, anadolu liselerinden mezun sınıf öğretmeni adayları tarafından alınan test geneli puanların aritmetik ortalaması $\bar{X}=12.10$, öğretmen liselerinden mezun öğretmen adayları tarafindan alınan test geneli puanların aritmetik ortalaması $\bar{X}=11.67$, mesleki ve teknik anadolu liselerinden mezun öğretmen adayları tarafından alınan test geneli puanların aritmetik ortalaması $\bar{X}=11.67$, düz liselerden mezun öğretmen adayları tarafından alınan test geneli puanların aritmetik ortalaması $\bar{X}=12.06$, diğer liselerden mezun öğretmen adayları tarafından alınan test geneli puanların aritmetik ortalaması ise $\overline{\mathrm{X}}=10.00$ olarak hesaplanmıştır. 
Tablo 15: Sınıf Öğretmeni Adaylarının SBÖBT’ten Aldıkları Puanların Mezun Olunan Lise Türü Değişkenine Göre Kruskal Wallis H-Testi Sonuçları

\begin{tabular}{|c|c|c|c|c|c|c|}
\hline & & $\mathbf{n}$ & $\begin{array}{c}\text { Sira } \\
\text { Ortalaması }\end{array}$ & sd & $\mathbf{X}^{2}$ & $\mathbf{p}$ \\
\hline \multirow{7}{*}{ B1 } & $\mathbf{A L}$ & 31 & 42.77 & \multirow{7}{*}{5} & \multirow{7}{*}{11.68} & \multirow{7}{*}{.095} \\
\hline & ÖL & 3 & 32.33 & & & \\
\hline & MTAL & 6 & 36.00 & & & \\
\hline & Aं̈HL & 1 & 63.50 & & & \\
\hline & DL & 31 & 46.61 & & & \\
\hline & Diğer & 9 & 19.28 & & & \\
\hline & Toplam & 81 & & & & \\
\hline \multirow{7}{*}{ B2 } & $\mathbf{A L}$ & 31 & 44.11 & \multirow{7}{*}{5} & \multirow{7}{*}{1.18} & \multirow{7}{*}{.947} \\
\hline & ÖL & 3 & 41.50 & & & \\
\hline & MTAL & 6 & 38.50 & & & \\
\hline & Aं̈HL & 1 & 31.00 & & & \\
\hline & DL & 31 & 39.15 & & & \\
\hline & Diğer & 9 & 39.28 & & & \\
\hline & Toplam & 81 & & & & \\
\hline \multirow{7}{*}{$\mathbf{T}$} & $\mathbf{A L}$ & 31 & 43.48 & \multirow{7}{*}{5} & \multirow{7}{*}{9.23} & \multirow{7}{*}{.100} \\
\hline & ÖL & 3 & 37.50 & & & \\
\hline & MTAL & 6 & 36.42 & & & \\
\hline & AİHL & 1 & 59.00 & & & \\
\hline & DL & 31 & 45.06 & & & \\
\hline & Diğer & 9 & 20.67 & & & \\
\hline & Toplam & 81 & & & & \\
\hline
\end{tabular}

Tablo 15'te yer alan SBÖBT'nin genelinden alınan toplam puan incelendiğinde, sınıf öğretmeni adaylarının sosyal beceri öğretimine ilişkin bilgi düzeylerinin mezun olunan lise türü değişkeni açısından anlamlı düzeyde farklılaşmadığı görülmektedir.

\section{Altıncı Araştırma Sorusuna Yönelik Bulgular}

Sınıf öğretmenlerinin sosyal beceri öğretimine ilişkin bilgi düzeyleri mezun olunan üniversite bölümü değişkenine göre farklılaşmakta mıdır? sorusuna yönelik bulgular Tablo 16 ve 17 'de sunulmuşstur.

Tablo 16: Mezun Olunan Üniversite Bölümü Değişkenine Göre SBÖBT’ten Alınan Puanlara İlişkin Betimsel İstatistikler

\begin{tabular}{ccccccccc}
\hline & & $\overline{\mathbf{X}}$ & Ortanca & Ss & Min. & Max. & Çarpıklık & Basıklık \\
\hline \multirow{3}{*}{ SÖ } & $\boldsymbol{B 1}$ & 8.15 & 8.00 & 2.15 & 2.00 & 12.00 & -.780 & .662 \\
& $\boldsymbol{B 2}$ & 3.15 & 3.00 & .96 & .00 & 4.00 & -1.092 & 1.151 \\
& $\boldsymbol{T}$ & 11.30 & 11.00 & 2.17 & 5.00 & 15.00 & -.805 & .932 \\
\hline \multirow{4}{*}{ Bö } & $\boldsymbol{B 1}$ & 9.63 & 8.50 & 2.07 & 8.00 & 13.00 & .800 & -1.264 \\
& $\boldsymbol{B 2}$ & 3.75 & 4.00 & .46 & 3.00 & 4.00 & -1.440 & - \\
& $\boldsymbol{T}$ & 13.38 & 12.00 & 2.27 & 11.00 & 17.00 & .759 & -1.333 \\
\hline \multirow{3}{*}{ Diğer } & $\boldsymbol{B 1}$ & 7.67 & 8.00 & 1.03 & 6.00 & 9.00 & -.666 & .586 \\
& $\boldsymbol{B 2}$ & 3.83 & 4.00 & .75 & 3.00 & 5.00 & .313 & -.104 \\
& $\boldsymbol{T}$ & 11.50 & 12.00 & 1.38 & 9.00 & 13.00 & -1.375 & 2.355 \\
\hline
\end{tabular}

Kısaltmalar: SÖ: Sinıf Ö̆gretmenliği; BÖ: Branş Ö̆gretmenliği 
Tablo 16 incelendiğinde, sınıf öğretmenliği bölününden mezun öğretmenler tarafindan alınan test geneli puanların aritmetik ortalaması $\overline{\mathrm{X}}=11.30$, branş öğretmenliğinden mezun öğretmenler tarafından alınan test geneli puanların aritmetik ortalaması $\bar{X}=13.38$, diğger bölümlerden mezun öğretmenler tarafından alınan test geneli puanların aritmetik ortalaması ise $\bar{X}=11.50$ olarak hesaplanmıştır.

Tablo 17: Sınıf Öğretmenlerinin SBÖBT’ten Aldıkları Puanların Mezun Olunan Üniversite Bölümü Değişkenine Göre Kruskal Wallis H-Testi Sonuçları

\begin{tabular}{|c|c|c|c|c|c|c|}
\hline & & $\mathbf{n}$ & $\begin{array}{c}\text { Sira } \\
\text { Ortalaması }\end{array}$ & sd & $\mathbf{X}^{2}$ & $\mathbf{p}$ \\
\hline \multirow{4}{*}{ B1 } & SÖ & 47 & 30.46 & \multirow{4}{*}{2} & \multirow{4}{*}{3.35} & \multirow{4}{*}{.187} \\
\hline & BÖ & 8 & 40.00 & & & \\
\hline & Diğer & 6 & 23.25 & & & \\
\hline & Toplam & 61 & & & & \\
\hline \multirow{4}{*}{ B2 } & SÖ & 47 & 28.44 & \multirow{4}{*}{2} & \multirow{4}{*}{5.04} & \multirow{4}{*}{.080} \\
\hline & ВÖ & 8 & 39.38 & & & \\
\hline & Diğer & 6 & 39.92 & & & \\
\hline & Toplam & 61 & & & & \\
\hline \multirow{4}{*}{$\mathbf{T}$} & SÖ & 47 & 29.06 & \multirow{4}{*}{2} & \multirow{4}{*}{4.23} & \multirow{4}{*}{.120} \\
\hline & BÖ & 8 & 42.81 & & & \\
\hline & Diğer & 6 & 30.42 & & & \\
\hline & Toplam & 61 & & & & \\
\hline
\end{tabular}

Tablo 17'de yer alan SBÖBT'nin genelinden alınan toplam puan incelendiğinde, sınıf öğretmenlerinin sosyal beceri öğretimine ilişkin bilgi düzeylerinin mezun olunan üniversite bölümü değişkeni açısından anlamlı düzeyde farklılaşmadığı görülmektedir.

\section{Yedinci Araştırma Sorusuna Yönelik Bulgular}

Sınıf öğretmenlerinin sosyal beceri öğretimine ilişkin bilgi düzeyleri mesleki hizmet yılı değişkenine göre farklılaşmakta mıdır? sorusuna yönelik bulgular Tablo 18 ve 19 'da sunulmuştur.

Tablo 18: Mesleki Hizmet Y1lı Değişkenine Göre SBÖBT’ten Alınan Puanlara İlişkin Betimsel İstatistikler

\begin{tabular}{ccccccccc}
\hline $\begin{array}{c}\text { Mesleki Hizmet } \\
\text { Yılı }\end{array}$ & $\overline{\mathbf{X}}$ & Ortanca & Ss & Min. & Max. & Çarpıklık & Basıklık \\
\hline \multirow{3}{*}{$\mathbf{0 - 1 0}$} & $\boldsymbol{B 1}$ & 8.50 & 9.00 & 1.51 & 6.00 & 11.00 & -.121 & -.401 \\
& $\boldsymbol{B} 2$ & 3.30 & 3.00 & .67 & 2.00 & 4.00 & -.434 & -.283 \\
& $\boldsymbol{T}$ & 11.80 & 12.00 & 1.87 & 8.00 & 15.00 & -.274 & 1.645 \\
\hline \multirow{4}{*}{$\mathbf{1 1 - 2 0}$} & $\boldsymbol{B} 1$ & 8.65 & 8.00 & 2.07 & 2.00 & 13.00 & -.645 & 2.127 \\
& $\boldsymbol{B} 2$ & 3.17 & 3.00 & 1.00 & .00 & 4.00 & -1.344 & 1.858 \\
& $\boldsymbol{T}$ & 11.82 & 12.00 & 1.98 & 6.00 & 17.00 & -.090 & 2.066 \\
\hline \multirow{2}{*}{$\mathbf{2 1 - 3 0}$} & $\boldsymbol{B 1}$ & 7.27 & 8.00 & 2.38 & 3.00 & 12.00 & .004 & -.044 \\
& $\boldsymbol{B} 2$ & 3.67 & 4.00 & .82 & 2.00 & 5.00 & -1.077 & .956 \\
& $\boldsymbol{T}$ & 10.93 & 11.00 & 2.89 & 5.00 & 16.00 & -.415 & -.012 \\
\hline \multirow{3}{*}{$\mathbf{3 1}$ ve üzeri } & $\boldsymbol{B} 1$ & 9.00 & 9.00 & 1.41 & 8.00 & 10.00 & - & - \\
& $\boldsymbol{T}$ & 2.50 & 2.50 & .71 & 2.00 & 3.00 & - & - \\
\hline
\end{tabular}


Tablo 18 incelendiğinde, 0-10 mesleki hizmet süresine sahip öğretmenler tarafından alınan test geneli puanların aritmetik ortalamas $\bar{X}=11.80$ olarak, $11-20$ y1l grubunda $\bar{X}=11.67,21-30$ y1l grubunda $\bar{X}=11.45,31$ ve üzeri y1l grubunda ise $\bar{X}=11.31$ olarak hesaplanmıştır.

Tablo 19: Sınıf Öğretmenlerinin SBÖBT’ten Aldıkları Puanların Mesleki Hizmet Yılı Değişkenine Göre Kruskal Wallis H-Testi Sonuçları

\begin{tabular}{|c|c|c|c|c|c|c|}
\hline & & $\mathbf{n}$ & $\begin{array}{c}\text { Sira } \\
\text { Ortalaması }\end{array}$ & sd & $\mathbf{X}^{2}$ & $\mathbf{p}$ \\
\hline \multirow{5}{*}{ B1 } & 0-10 & 10 & 32.50 & \multirow{5}{*}{3} & \multirow{5}{*}{4.56} & \multirow{5}{*}{.207} \\
\hline & $11-20$ & 34 & 33.81 & & & \\
\hline & 21-30 & 15 & 22.77 & & & \\
\hline & 31 ve üzeri & 2 & 37.50 & & & \\
\hline & Toplam & 61 & & & & \\
\hline \multirow{5}{*}{ B2 } & $0-10$ & 10 & 29.40 & \multirow{5}{*}{3} & \multirow{5}{*}{5.47} & \multirow{5}{*}{.140} \\
\hline & $11-20$ & 34 & 29.32 & & & \\
\hline & 21-30 & 15 & 38.13 & & & \\
\hline & 31 ve üzeri & 2 & 14.00 & & & \\
\hline & Toplam & 61 & & & & \\
\hline \multirow{5}{*}{$\mathbf{T}$} & $0-10$ & 10 & 32.35 & \multirow{5}{*}{3} & \multirow{5}{*}{.77} & \multirow{5}{*}{.857} \\
\hline & $11-20$ & 34 & 32.16 & & & \\
\hline & 21-30 & 15 & 27.67 & & & \\
\hline & 31 ve üzeri & 2 & 29.50 & & & \\
\hline & Toplam & 61 & & & & \\
\hline
\end{tabular}

Tablo 19'da yer alan SBÖBT'nin genelinden alınan toplam puan incelendiğinde, sınıf öğretmenlerinin sosyal beceri öğretimine ilişkin bilgi düzeylerinin mesleki hizmet süresi değişkeni açısından anlamlı düzeyde farklılaşmadığı görülmektedir.

\section{Sonuç, Tartıșma ve Öneriler}

Sosyal becerilerin gerek olağan gelişim özellikleri gösteren gerekse de özel eğitim ihtiyac1 olan bireylerin toplum içinde etkin ve bağımsız birer birey olarak yaşayabilmeleri noktasında önemli ve işlevsel beceriler olduğu düşüncesinden hareketle, bu araştırmada sınıf öğretmenleri ile sınıf öğretmeni adaylarının sosyal beceri öğretimine ilişkin bilgi düzeylerinin çeşitli değişkenler açısından incelenmesi ve karşılaştırılması amaçlanmıştır. Bu amaç ve araştırmadan elde edilen bulgular doğrultusunda SBÖBT’ten alınabilecek en yüksek puan Max.=23.00 iken; araştırmaya katılan sınıf ögretmenlerinin testten ortalama $\bar{X}=11.60$, sınıf öğretmeni adaylarının ise $\bar{X}=11.81$ puan aldıkları belirlenmiştir. Dolayısıyla sınıf öğretmenleri ile sınıf öğretmeni adaylarının sosyal beceri öğretimine ilişkin bilgi düzeylerinin orta düzeyde olduğu ve birbirlerinden anlamlı düzeyde farklılaşmadığı sonucuna ulaşılmıştır. Ayrıca elde edilen araştırma bulguları doğrultusunda öğretmen ve öğretmen adaylarının sosyal beceri öğretimine ilişkin bilgi düzeylerinin cinsiyet, yaş, mesleki hizmet yıllı, mezun olunan lise türü ve üniversite bölümü değişkenleri açısından anlamlı düzeyde farklılaşmadığı sonucuna ulaşılmıştır.

Nitekim bu bağlamda gerek sınıf öğretmenlerinin gerekse de sınıf öğretmeni adaylarının sosyal beceri öğretim düzeyine ilişkin bilgi düzeylerinin orta düzey olduğu sonucu önceki araştırma bulgularıyla farklılık göstermektedir. Kaynaştırma sınıfı öğretmenlerinin sosyal beceri öğretimine ilişkin bilgi düzeylerini belirlemek ve çalıştıkları sınıf düzeyi ile eğitimlerinin bilgi düzeyleri üzerinde fark yaratıp yaratmadığını araştırmak amacıyla Sazak Pınar, Sucuoğlu ve Çıkrıkçı Demirtaşlı (2013) tarafından yürütülen araştırmada, öğretmenlerin en yüksek 23 puan alınabilecek 
SBÖBT’ten en düşük 3, en yüksek 15, ortalama 9,85 puan aldıkları bulgulanmış olup öğretmenlerin sosyal beceri öğretimine ilişkin bilgilerinin sınırlı olduğu sonucuna ulaşılmıştır. Ayrıca, Sazak Pınar (2012) tarafından yürütülen bir diğer araştırmada ise öğretmen adaylarının sosyal beceri öğretimine ilişkin bilgi düzeylerini belirlemek ve öğretmen adaylarının sosyal beceri öğretimine ilişkin bilgi düzeylerinin devam ettikleri program türüne göre değişip değişmediğini incelemek amaçlanmış olup, bu amaç doğrultusunda elde edilen bulgular öğretmen adaylarının sosyal beceri öğretimine ilişkin bilgilerinin sınırlı düzeyde olduğu yönündedir. Öğretmenlerin sosyal beceri öğretimi bilgi düzeylerinin yetersizliğini ortaya koyan bir diğer araştırma da Güner Yıldız (2017) tarafindan yapılmış olup sınıf öğretmenlerinin en fazla 23 puan alınabilen SBÖBT'ten ortalama 12,4 puan aldıkları ve öğretmenlerin sosyal beceri öğretimine ilişkin bilgi düzeylerinin üzerinde cinsiyet değişkenlerinin etkisinin olmadığı sonucuna ulaşılmıştır. Ayrıca ilgili alanyazında öğretmenlerin sosyal beceri öğretimine ilişkin bilgi düzeylerinin farklı araştırma yöntemleriyle incelendiği başka araştırmalar da (Cheney ve Barringer, 1995; Çolak, Vuran ve Uzuner, 2013; Dobbins ve Higgins, 2010; Lane, 1999; Lane, O’Shaughnessy, Lambros, Gresham ve Beebe-Frankenberger, 2001; Lane ve Menzies, 2005; Vlachou, Stavroussi ve Didaskalou, 2016; Vuran ve Çolak, 2007) yer almaktadır. Yapılan bu araştırmalarda da öğretmenlerin sosyal beceri öğretimine ilişkin bilgi düzeylerinin sınırlı düzeyde olduğu saptanmıştır.

Sonuç olarak, sınıfında özel gereksinimli öğrenci bulunan sınıf öğretmenleri ile sınıf öğretmeni adaylarının farklı potansiyel, fiziksel ve/veya zihinsel özelliklere sahip tüm öğrencilere sosyal becerilerin öğretilmesi noktasında sorumluluk üstlenmeleri gerekmektedir. Bu gereklilik doğrultusunda sosyal beceri öğretimi öğretmenlerin keyfiyetine bırakılmaksızın eğitim-öğretim programlarının bir parçası olmalı, öğrencilerin okul ortamında edinmiş oldukları sosyal becerileri doğal ortamlarda kullanabilmeleri ve sosyal yeterliklerini geliştirebilmeleri için firsatlar yaratılmalıdır. Nitekim bu bağlamda sosyal beceri öğretiminin akademik beceri öğretiminden ayrı tutulması yönündeki düşüncelerinin aksine, ilgili alanyazında sosyal becerilerin gerek akademik başarı gerekse de akranlarla nitelikli etkileşim kurabilmeleri noktasında öğrenciler için önkoşul beceriler olduğu ve dolayısıyla akademik beceri ve sosyal beceri ögretiminin okulların eğitimöğretim programlarında birlikte planlanmasının ve sürdürülmesinin gerekliliği üzerinde önemle durulmaktadır.

Öğretmen ve öğretmen adaylarının sosyal beceri öğretimiyle ilgili temel kavram, öğretim yöntem ve tekniklerine yönelik bilgi düzeylerinin orta düzey olduğunu ortaya koyan bu araştırma sonuçlarına ilişkin olarak geliştirilen öneriler daha kapsamlı bir şekilde aşağıdaki gibi maddelendirilebilinir:

- Eğitim fakültelerinde öğretmen adaylarının sosyal beceri öğretimine ilişkin bilgi düzeylerini geliştirmeye yönelik çalışmaların yaygınlaştırılmasının,

- Sınıf öğretmenlerin ve sınıf öğretmeni adaylarının gerek olağan gelişim özellikleri gösteren gerekse de özel eğitim ihtiyacı olan öğrencilerin sosyal becerilerini geliştirmeye yönelik bilgi ve deneyimlerini etkin hale getirecek çalışmaların yapılmasinin,

- Sosyal becerileri gelişmiş öğretmenlerin yetiştirilmesi adına branşa bakılmaksızın tüm öğretmen yetiştirme lisans programlarına sosyal becerileri öğretimine yönelik zorunlu derslerin eklenmesinin,

- Sosyal becerilerin önemine ve öğretimine ilişkin olarak daha ayrıntılı ve işlevsel açıklamalar kapsamında eğitim-öğretim programlarının yeniden düzenlenmesinin,

- Öğretmenlerin ders içi ve ders dış1 etkinliklerde sosyal beceri öğretimine nası1 yer verebilecekleri konusunda bilgilendirilmesi amacıyla sosyal beceri öğretiminin temel bir konu olarak ele alındığı hizmet öncesi ve hizmet içi programların düzenlenmesinin,

- Sosyal becerileri öğretiminde kalıcılık ve genellemenin sağlanması amacıyla ailelere 
yönelik ev merkezli aile eğitim programlarının hazırlanmasının,

- İleriki araştırmalara yönelik olarak alanda çalışan öğretmen ve öğretmen adaylarının sosyal beceri öğretimi konusundaki bilgi ve becerilerini arttırmak amacıyla deneysel araştırmaların yürütülmesinin faydalı olabileceği söylenebilir.

\section{Kaynakça}

Arl1, M. ve Nazik, H. (2004). Bilimsel araştırmaya giriş. Ankara: Gazi Kitapevi.

Avcıŏlu, H. (2012). Zihinsel yetersizliği olan çocuklara sosyal beceri kazandırmada işbirliğine dayalı öğrenme ve drama yöntemlerinin etkililiğii. Eğitim ve Bilim. 37 (163), 110-125.

Begun, W. R. (Ed.). (1996). Social skills lessons and activities for grades 7-12. San Francisco, CA: Jossey-Bass.

Bellini, S., Peters, J. K., Benner, L. ve Hopf, A. (2007). A meta-analysis of school-based social skills interventions for children with autism spectrum disorders. Remedial and Special Education, 28 (3), 153-162.

Büyüköztürk, Ş., Çakmak, E. K., Akgün, Ö. E., Karadeniz, Ş. ve Demirel F. (2016). Bilimsel araştirma yöntemleri. Ankara: Pegem A Akademi.

Campbell, P. ve Siperstein, G. (1994). Improving social competence: Are source for elementary school teachers. Needhamheights, MA: Ally \& Bacon.

Cavell, T. A. (1990). Social adjustment, social performance and social skills: A tricomponent model of social competence. Journal of Clinical Child Psychology, 19, 111-122.

Cheney, D. ve Barringer, C. (1995). Teacher competence, student diversity, and staff training for the inclusion of middle school students with emotional and behavioral disorders. Journal of Emotional and Behavioral Disorders, 3 (3), 174-182. https://doi.org/10.1177\%2F106342669500300307

Çolak, A., Vuran, S. ve Uzuner, Y. (2013). Kaynaştırma uygulanan bir ilköğretim sınıfındaki sosyal yeterlik özelliklerinin betimlenmesi ve iyileştirilmesi çalışmaları. Ankara Üniversitesi Eğitim Bilimleri Fakültesi Özel Eğitim Dergisi, 14 (02), 33-53.

Dobbins, N. ve Higgins, K. (2010). An analysis of social skills instruction provided in teacher education and in- service training programs for general and special educators. Remedial and Special Education. 31 (5), 358-367.

Elliott, N. S. ve Gresham, F. M. (1987). Children's social skills assessment and classification practices. Journal of Counseling and Development. 66, 96-99.

Elliott, S. N. ve Gresham, F. M. (1993). Social skills interventions for children. Behavior Modification, 17, 287-313.

Ergenekon, Y. (2017). Sosyal yeterlikle ilişkili kavramlar ve sosyal yeterliğin bileşenleri. Vuran, S. (Ed.). Sosyal Yeterliklerin Geliştirilmesi içinde. Ankara: Vize Yayıncılık.

Gresham, F. M. (1997). Social competence and students with behavior disorders: Where we've been, where we are and where we should go. Education and Training in Mental Retardation and Developmental Disabilities, September, 194-201.

Gresham, F. M., Sugai, G. ve Horner, R. H. (2001). Interpreting outcomes of social skills training for students with high-incidence disabilities. Exceptional Children, 67, 331-344. 
Sınıf Öğretmenleri ile Sınıf Öğretmeni Adaylarının Sosyal Beceri Öğretimine İlişkin Bilgi... 1119

Güner Yıldız, N. (2017). Öğretmenlerin Sosyal Beceri Öğretimine Yönelik Bilgi Düzeyleri ile Öğrencilerin Sosyal Becerileri Arasındaki İlişki. İlköğretim Online, 16 (3), 1275-1286. http://dx.doi.org/10.17051/ilkonline.2017.330257

Karasar, N. (2012). Bilimsel araştırma yöntemi (24. bs.). Ankara: Nobel Yayıncılık.

Lane, K. L. (1999). Young students at risk for antisocial behavior: The utility of academic and social skills interventions. Journal of Emotional and Behavioral Disorders, 7 (4), 211-223.

Lane, K. L., Menzies, H. M., Barton-Arwood, S. M., Doukas, G. L., ve Munton, S. M. (2005). Designing, implementing, and evaluating social skills interventions for elementary students: Step-by-step procedures based on actual school-based investigations. Preventing School Failure, 49 (2), 18-26.

Lane, K. L., O’Shaughnessy, T., Lambros, K. M., Gresham, F. M. ve Beebe-Frankenberger, M. E. (2001). The efficacy of phonological awareness training with first-grade students who have behavior problems and reading difficulties. Journal of Emotional and Behavioral Disorders, 9, 219-231.

Margalit, M. (1993). "Social Skills and Classroom Behavior among Adolecents with Mild Mental Retardation". American Journal on Mental Retardation, 97 (6), 685-691.

Mastropieri, M. A. ve Scruggs, T. E. (2000). The inclusive classroom: Strategies for effective instruction. Upper Saddle River, NJ: Merrill.

Merrell, K. W. ve Gimpel, G. A. (1998). Social skills of children and adolescents: conceptualizatio, assessment, treatment. New Jersey: Lawrence Erlbaum Associates, Inc.

Meşeci, F. (2008). Öğretmenin sosyalleştirici rolü ve istenmeyen davranışlarla başa çıkma. Hasan Ali Yücel Ĕ̈itim Fakültesi Dergisi, 1, 115-125.

Olçay Gül, S. (2018). Sosyal beceri ve sosyal yeterlik. Çifci Tekinarslan, İ. ve Öncül N. (Ed.). Özel Ĕgitimde Sosyal Uyum Becerilerinin Öğretimi içinde (s. 3). Ankara: Vize Akademik.

Sazak Pınar, E. (2009). Kaynaştırma sınıfi ögretmenlerinin sosyal becerilere ilişkin beklentileri ve sosyal beceri ögrretim programının ögretmen çıktıları üzerindeki etkililiğinin incelenmesi. Doktora Tezi. Ankara Üniversitesi, Eğitim Bilimleri Enstitüsü, Ankara.

Sazak Pınar, E. (2012). Öğretmen Adaylarının Sosyal Beceri Öğretimine İlişkin Bilgi Düzeylerinin Belirlenmesi. Illköğretim Online, 11 (1), 201-213.

Sazak Pınar, E., Sucuoğlu, B. ve Demirtaşlı, N. Ç. (2013). Sınıfında özel gereksinimli öğrenci bulunan öğretmenlerin sosyal beceri öğretimine ilişkin bilgi düzeylerinin belirlenmesi. Ĕgitim ve Bilim, 38 (168), 203-244.

Selçuk, Z. (2012). Eğitim psikolojisi. Ankara: Nobel Yayınc1lık.

Sucuoğlu, B. ve Çifci, İ. (2001). Yapamıyor mu? Yapmıyor mu? Zihinsel engelli çocuklar için sosyal beceri ögretimi. Ankara: Ankara Üniversitesi Basımevi.

Vlachou, A., Stavroussi, P. ve Didaskalou, E. (2016). Special teachers' educational responses in supporting students with special educational needs (sen) in the domain of social skills development. International Journal of Disability, Development and Education, 63 (1), 7997. https://doi.org/10.1080/1034912X.2015.1111305

Vuran, S. (2005). The sociometric status of students with disabilities in elementery level integration classes in Turkey. Eğitim Araştırmaları Eurasion Journal of Educational Research. 18, $217-$ 235 . 
Vuran, S. ve Çolak, A. (2007). İlköğretim kaynaştırma sınıfi öğretmenlerinin kaynaştırmaya ve sosyal beceri öğretimine iliş̧kin görüşleri. 17. Ulusal Özel Eğitim Kongresi'nde sunulan bildiri. 15-17 Kasım 2007, Çeşme, İzmir.

Zirpoli, T. J. ve Melloy, K. J. (1997). Behavior managemant: Applications for teachers and parents. New Jersey: Prentice-Hall, Inc. 